\title{
Assisted reproductive techniques in wisents: Achievements and further challenges*
}

\author{
MARIA EBERHARDT ${ }^{1}$, WOJCIECH NIŻAŃSKI ${ }^{1}$, WANDA OLECH ${ }^{2}$, SYLWIA PROCHOWSKA $^{1}$ \\ ${ }^{1}$ Department of Reproduction and Clinic of Farm Animals, Veterinary Faculty, \\ University of Environmental Science, Grunwaldzki Square 49, 50-357 Wroclaw, Poland \\ ${ }^{2}$ Department of Animal Genetics and Conservation, Institute of Animal Sciences, \\ Warsaw University of Life Sciences, Ciszewskiego 8 St., 02-786 Warsaw, Poland
}

\section{Eberhardt M., Niżański W., Olech W., Prochowska S. Assisted reproductive techniques in wisents: Achievements and further challenges}

Summary

The current population of wisents (Bison bonasus, Linnaeus 1758) originates from only 12 individuals that survived World War II in zoos and private enclosures. For better preservation of genetic variability, research is being conducted to introduce assisted reproductive techniques in this species. In this article, we describe the current state of knowledge and prospects for further development in this field.

The article is divided into sections dealing with semen collection and preservation, artificial insemination, oocyte collection, in vitro fertilization and embryo transfer, and further challenges.

Keywords: wisent, Bison bonasus, biodiversity, assisted reproductive techniques, cryopreservation

In the past several decades, assisted reproductive techniques (ART) have played an important role in veterinary medicine. They have been widely adopted in the field of livestock and companion animal breeding $(1,5,11,64)$. Semen cryopreservation, artificial insemination (AI) and embryotransfer (21, 22, 63) are used in cattle reproduction. Procedures for the preservation of liquid boar semen and AI have been developed (58). In the reproduction of accompanying animals, such as dogs or horses, artificial insemination is performed with both fresh and preserved semen $(3,64)$. These methods are also widely regarded as promising in protection and restitution of endangered animals $(40,44)$. A common strategy used in species protection is creation of preserves and national parks that protect natural habitats. An alternative approach to the problem is an ex situ protection with a possibility of implementing breeding programs. Well-known and still developing techniques are a starting point for research into adapting them to use in the reproduction of wild animals. Many research centres all over the world create banks of frozen gametes and tissues obtained from endangered species, which constitute a genetic reserve and material for further research in this field $(10,33,51)$.

* This research was funded by the Forest Fund (Poland), grant number OR.271.3.10.2017 (Badania finansowane ze środków Funduszu Leśnego zgodnie $\mathrm{z}$ umową nr OR.271.3.10.2017).
The wisent (Bison bonasus, Linnaeus 1758) is a species that has undergone the bottleneck effect (52). Pedigree books show that all currently living individuals come from 12 ancestors, which survived World War II in zoos and private pens $(46,62)$. The dangers of mating closely related individuals include the increased probability of accumulation of unfavourable features, susceptibility to certain diseases, increased incidence of malformations, decreased fertility, infertility or a low survival rate of newborns $(54,55)$. Prior studies of wisents have revealed changes occurring in the male reproductive system, such as cryptorchidism, epididymal cysts, necrotic inflammation of the prepuce and an increased incidence of a high percentage of morphological sperm defects (29). Therefore, one of the major topics investigated in this field is minimizing the loss of genetic variability. A way to overcome these problems could be genetic profiling of herds in captivity and selection of least related individuals for mating. In this respect, there are two methods of reproduction of thus selected animals: by mating or using assisted reproductive techniques, such as collection and preservation of semen, artificial insemination, in vitro oocyte collection and maturation, in vitro fertilization and embriotransfer, which have been successfully used and described in many wild mammal species, including felines, canines or deer $(14,25,41,44,48)$. Successive gamete collection and banking, development of in vitro 
fertilization techniques, obtaining embryos from possibly genetically diverse parents and embryo transfer make it possible to plan long-term activities aimed at the restitution of wisents. However, those methods have their limitations, which will be discussed in this publication. To the authors' knowledge, no previous review has been devoted to wisents in this field. The aim of this paper is to present the current state of knowledge on the possibility of using ART to protect the genetic diversity of this species, past achievements in their application and further challenges.

\section{Collection and preservation of spermatozoa}

Semen collection techniques, such as the use of an artificial vagina or the flushing of spermatozoa from the female genital tract, are technically difficult in the case of wild animals. The literature review shows that only use of electroejaculation has been described in wisents (49). However, this method requires general anaesthesia and for this reason is seen as incompatible with wild animal welfare broadly understood and is not accepted by many researchers for ethical reasons (44). What is more, as was shown in other species, the quality of semen obtained by this method is not always satisfactory (44). An alternative approach is to obtain male germ cells post mortem (30) from animals that have died or have been culled under conditions regulated by Polish law (The Nature Conservation Act 2004). Spermatozoa are obtained by performing multiple incisions of the epididymal tail and immersing tissue in a sperm-optimized medium, e.g. a Tris-based extender. Thereby, sperm cells characterized by progressive movement are released into the extender (44). It is a simple and effective procedure, but contamination of the sample with epididymal detritus is unavoidable, which may negatively affect sperm quality. The use of additional filters separating epididymal tissue and erythrocytes is required (38). The main practical limitation of this method is that the quality of sperm obtained depends on the interval between the death of the animal and spermatozoa collection (59). Previous studies on the characteristics of sperm obtained from ram epididymides has proven that up to 24 hours after the death of the animal the basic parameters of epididymal sperm (viability, percentage of gametes with progressive movement) are comparable to those of ejaculated semen. Beyond this time, however, a gradual drop in quality was observed $(38,59)$. On the other hand, similar studies on the quality of sperm obtained from bull epididymides have shown the possibility of using them up to 72 hours after the death of the animal (39). Since this technique can be used only once, it is not routinely used in animal reproduction. Nevertheless, in the case of endangered species, it offers the possibility of creating valuable genetic reserves despite the animal's death (44), as has been proven in ruminants (43), Canidae (42), Felidaea (17) and Cervidae (38).
Semen cryopreservation procedures in wisents are based on technologies used in other ruminants $(30,49)$. Several previous attempts to freeze sperm obtained both by electroejaculation and post mortem were conducted with a Tris-based extender $(30,49)$. Acceptable results (frozen/thawed: MOT 11- 48\%, PMOT: 8-20\%) were obtained after using a diluent containing Tris, citric acid, glucose, egg yolk, penicillin, streptomycin, glycerol and distilled water (30). The effectiveness of commercial diluents intended for cattle has also been proven $(30,49)$. Currently, in reproductive biotechnology, there is a growing tendency to avoid diluents containing animal products. Egg yolk or milk may be a potential source of pathogenic microorganisms, such as avian influenza virus, Salmonella sp., Escherichia coli or mycoplasmas (71). Elimination of potential pathogens from the gamete conservation process is important for creating stable genetic reserves and, in the future, for obtaining disease-free progeny $(25,34$, 71). Currently, in research on the development of optimal extenders free of exogenous protein for various animal species, cyclodextrins are of a great interest $(6,9,53,71)$. Successful attempts to cryopreserve semen with media enriched with a complex of cyclodextrin and cholesterol were made in Bison bison athabascae, the effectiveness of which was confirmed in vitro and in vivo (71). Considerable attention is also given to other semen additions, such as sericin (2), caffeine (61), melatonin (12) and antioxidants, such as vitamin $\mathrm{C}$ or polyphenols (70), which have not been tested in wisents.

As part of the project initiated by a team from the University of Life Sciences in Wrocław to create a Bio Ark associating zoos and scientific centres from Poland, France (Alfort), Germany (Berlin), Italy (Milan), Belgium (Ghent), Sweden (Uppsala) and Ukraine, the Wrocław Semen Bank of Companion and Wild Animals stores fibroblasts, spermatozoa and oocytes from over 30 animal species, including wisents (26 males). Reproductive cells are obtained by the incision method and frozen in liquid nitrogen vapour using commercial and laboratory-made media (30). Each time, after isolation from the epididymis, sperm cells are subjected to a basic analysis (concentration, morphology, viability) and an advanced analysis using a computer-assisted semen analysis system (CASA) and flow cytometry. The basic features of sperm function, i.e. motility and physiological parameters, such as cell membrane integrity, acrosome integrity and mitochondrial activity, are evaluated. Each time, the decision on the cryopreservation of sperm cells and their further use in research is based on the results obtained.

\section{Artificial insemination}

To the best of our knowledge, there has been no research on the procedure of artificial insemination in wisents. In order to test the fertilizing capacity of 
cryopreserved wisent sperm, an attempt was made to artificially inseminate Holstein-Friesian domestic cattle (30). That study used spermatozoa isolated post mortem from epididymis, which was subsequently cryopreserved in liquid nitrogen vapour (30). As a result of the experiment, pregnancy was obtained in two heifers. One pregnancy ended after 253 days in preterm labour by caesarean section, and the other after 264 days of pregnancy (30). Therefore, the capacity of wisent spermatozoa obtained and preserved by the above procedure to fertilize oocytes and thereby generate an interspecies hybrid was demonstrated (30).

The possibility of using the technique of AI in herds kept on farms has been demonstrated in the wood bison, closely related to the wisent (71). Yang et al. (71) made an attempt to synchronize oestrus during the season by two methods: one was based on follicle ablation and the other involved using intravaginal steroid systems. In both groups, PGF2 and hCG were injected at different times after the administration of prostaglandin (71). There was no difference in the effectiveness of ovulation induction between these two methods (71). Then, an artificial insemination procedure was performed. As a result, healthy wood bison calves were obtained (71). The example of the wood bison may inspire attempts to use oestrus synchronization and artificial insemination in similarly maintained wisent herds.

\section{Oocyte harvesting, in vitro fertilization and embryo transfer}

OPU (Ovum Pick Up) is a method routinely used for the collection of human oocytes $(27,36)$, but it is also used in ruminants $(37,67-69)$ and pigs (7). This method is based on the supravital collection of immature oocytes by puncture of the ovarian follicle and aspiration under ultrasound guidance (56). However, due to the required anaesthesia and other difficulties, the laparoscopic method of obtaining oocytes is not always feasible in wild animals. Therefore, in free-living females, the optimal method seems to be the isolation of oocytes from gonads collected post mortem, as in the case of male gametes. Oocytes can be obtained by incising the ovaries, puncturing the follicles or aspirating the follicular fluid (13). According to studies on buffalo ovaries, oocytes can be obtained most effectively by the incision method (13). This procedure involves the release of oocytes into the medium by making a series of incisions in the ovarian tissue (32). The basis of media used for oocyte harvesting is TCM-199 or PBS, or TYH, enriched with various substances, such as BSA, FCS, HEPES (buffer) or antibiotics (gentamicin, streptomycin, penicillin G) (32).

Female gametes differ significantly from sperm or embryos in terms of their preservation tolerance (57). The surface to volume ratio is much lower for oocytes than it is for male gametes, which makes them more sensitive to cooling and susceptible to intracellular crystallization (57). Additionally, this sensitivity is exacerbated by the high lipid ooplasm content. What is more, the lower number of sub-membrane actin microtubules makes the oocyte cell membrane less robust and therefore susceptible to damage during the preservation process (57). Therefore, for purposes of species protection and the related ART, it is important to develop an optimal method of oocyte conservation. The techniques used in humans and other species include programmed freezing and vitrification $(18,44)$. These methods differ fundamentally in terms of the mechanism responsible for the formation of intracellular changes (19). The process of oocytes freezing is based on solidifying the gradually cooled intracellular fluid by crystallization in the presence of media with a few percent addition of cryoprotective substances $(19,44)$. Vitrification consists in the rapid freezing of oocytes by immersing them in liquid nitrogen Although this method eliminates cell damage due to the crystallization process, it requires the use of a high concentration of protective compounds, which can often cause damage to gametes subjected to cryopreservation (19). Nevertheless, vitrification is an effective method of preserving oocytes of many animal species (19). There are no studies on the optimization of the cryopreservation process of wisent oocytes. The aforementioned wisent sperm cryopreservation procedures are based on protocols used for cattle. That suggests the possibility of using cryopreservation procedures dedicated to bovine oocytes. Vitrification in a mixture based on DMSO and ethylene glycol or DMSO, propylene glycol and acetamide resulted in a high percentage (nearly $90 \%$ ) of morphologically normal bovine oocytes after thawing (19). Vitrification has been shown to be effective in the process of cryopreservation of both mature oocytes (in metaphase II) and immature oocytes (in the GV phase) (19), which is of particular importance in the case of wisent females from which oocytes will be obtained immature.

In vitro fertilization (IVF) techniques used in endangered species protection programmes could become an extremely valuable tool for obtaining offspring from individuals with reduced fertility, from isolated populations, and even many years after the death of the animal, using gametes stored in cell banks $(8,14$, $25,28,35,40,41,49)$. As reported in the literature, in vitro fertilization has been performed in some wild ruminants (4) and in over 10 species of the Felidae family (14) (40). The effectiveness of classical in vitro fertilization depends on the semen quality, which is not always high in the case of semen from wild animals (28). However, the technique of injecting sperm directly into the ooplasm (ICSI) makes it possible to obtain offspring despite unsatisfactory sperm parameters. The usefulness of ICSI has been demonstrated in wild felids, in which the quality of sperm is often insufficient to conduct the classical procedure of in vitro fertilization. However, it is an expensive tech- 
nique, requiring appropriate equipment and qualified personnel (28). The effective application of classical in vitro fertilization in cattle and efforts to improve the quality of post-thawed wisent semen give hope that the introduction of ICSI into the wisent biodiversity protection programme will not be necessary.

Further research on wisent reproduction made it possible to obtain, as a result of classical in vitro fertilization, an early blastocyst from germ cells collected post mortem (16).

So far, it has not been possible to obtain wisent calves through the in vitro fertilization procedure. However, there are reports in the literature of successful in vitro fertilization and embryo transfer in the wood bison. In an experiment, single blastocysts were transferred to 5 recipients. In two of them, pregnancies were obtained, which ended in the birth of healthy calves after 264 and 269 days (66).

Nevertheless, in the case of wild and protected animals, the transfer of embryos to recipients of the same species is extremely difficult and will not always be possible. One way to overcome these problems is to find a suitable common species whose females could become recipients of developing wisent embryos. Tests with artificial insemination of domestic cattle females with wisent sperm suggest that cattle will be able to give birth to wisent calves, as demonstrated in the case of the Holstein-Friesian breed (30). In addition, it is a breed with a low rate of birth complications (26) and embryo transfer that has been perfected and described in numerous publications $(20,23,31,47)$.

\section{Further challenges}

The main purpose of wisent conservation in Poland is to ensure the sustainability of the captive part of population, its further development and the protection of its genetic variability and health. The aim of ART developed for this purpose is to obtain heterogeneous offspring through combining in vitro gametes from the least related individuals. This could become a valuable tool for preservation of the species and for exchange of these animals between herds. First successes, such as the cryopreservation of reproductive cells or obtaining an early blastocyst in vitro, have been reported. It should be noted, however, that the vast majority of banked sperm, as well as oocytes, used in in vitro fertilization procedures are obtained posthumously out of the reproductive season. This may have consequences in a reduced ability of reproductive cells to fertilize and develop the embryo (15). What is more, male reproductive cells become fully capable of fulfilling their function only in the female reproductive tract. Therefore, spermatozoa obtained from the epididymis are not fully competent. It is particularly important to continue research on the preparation and selection of gametes for in vitro fertilization in order to increase the chance of proper embryo development. The results of experiments in oocyte maturation, in vitro fertilization and maturation of embryos carried out so far require verification on more extensive material. The fact that wood bison calves have been obtained by in vitro fertilization (66) offers a new insight and a promise that in the long run this will also be possible in wisents. Another equally interesting option for protection of the European bison's gene pool is the use of pluripotent stem cells, which, when properly programmed, can differentiate into any type of somatic cells and gametes (15).

Despite significant progress in research on the introduction of assisted reproductive techniques in the wisent, additional studies are required. However, successes in conservation programmes for other endangered species have shown that these methods are effective tools for protection of intra-species diversity. They constitute a source of valuable information that should be used in further efforts under the comprehensive wisent protection programme.

\section{References}

1. Abecia J. A., Forcada F., González-Bulnes A.: Hormonal control of reproduction in small ruminants. Animal Reproduction Science 2012, 130, 173-179.

2. Aghaz F., Khazaei M., Vaisi-Raygani A., Bakhtiyari M.: Cryoprotective effect of sericin supplementation in freezing and thawing media on the outcome of cryopreservation in human sperm. Aging Male 2018, 19, 1-8.

3. Aurich J. E.: Artificial Insemination in Horses - More than a century of practice and research. Journal of Equine Veterinary Science 2012, 32, 458-463.

4. Bainbridge D. R. J., Catt S. L., Evans G., Jabbour H. N.: Successful in vitro fertilization of in vivo matured oocytes aspirated laparoscopically from red deer hinds (Cervus elaphus). Theriogenology 1999, 51, 891-898

5. Barbas J. P., Mascarenhas R. D.: Cryopreservation of domestic animal sperm cells. Cell Tissue Bank 2009, 10, 49-62.

6. Belala R., Fatmi S., Kaidi R., Iguer-Ouada M.: Benefits of cholesterol and $\alpha$-tocopherol loaded cyclodextrins in dog semen cryopreservation. Revue de Médecine Vétérinaire 2016, 167, 22-27.

7. Brüssow K. P., Torner H., Rátky J., Hunter M. G., Nürnberg G.: Ovum pick up in swine: the influence of aspiration vacuum pressure on oocyte recovery from preovulatory follicles. Acta Veterinaria Hungarica 1997, 45, 189-196.

8. Chatdarong K., Axner E., Manee-In S., Thuwanut P., Linde-Forsberg C.: Pregnancy in the domestic cat after vaginal or transcervical insemination with fresh and frozen semen. Theriogenology 2007, 68, 1326-1333.

9. Choi Y., Toyoda Y.: Cyclodextrin removes cholesterol from mouse sperm and induces capacitation in a protein-free medium. Biology of Reproduction 1998, 59, 1328-1333.

10. Clarke A. G.: The Frozen Ark Project: the role of zoos and aquariums in preserving the genetic material of threatened animals. International Zoo Yearbook 2009, 43, 222-230.

11. Cseh S., Faigl V., Amiridis G. S.: Semen processing and artificial insemination in health management of small ruminants. Animal Reproduction Science 2012 130, 187-192.

12. Dai G. C., Meng Y., Zhang L. K., Du Y. Q., Wen F., Feng T. Y., Hu J. H.: Effect of addition of melatonin on liquid storage of ram semen at $4^{\circ} \mathrm{C}$. Andrologia 2019, 51, 13236.

13. Das G. K., Jain G. C., Solanki V. S., Tripathi V. N.: Efficacy of various collection methods for oocyte retrieval in Buffalo. Theriogenology 1996, 46, 1403-1411.

14. Donoghue A. M. Johnston L. A., Seal U. S., Armstrong D. L., Tilson R. L., Wolf P., Petrini K., Simmons L. G., Gross T., Wildt D. E.: In vitro fertilization and embryo development in vitro and in vivo in the tiger (Panthera tigris). Biology of Reproduction 1990, 43, 733-744.

15. Duszewska A. M.: Cellular technologies (in vitro production of embryos, germplasm preservation and somatic reprogramming) for wisent (European bison) gene pool conservation. Concepts of Dairy \& Veterinary Sciences 2020, 3, 338-340.

16. Duszewska A. M., Gręda P., Baraniewicz M., Bielecki W., Niżański W., Partyka A., Tracz M., Nowak Z., Chetmońska-Soyta A., Olech W.: Obtaining wisent early blastocyst in vitro is a basic for protection and creation of biodiversity for this threatened species. Reproduction in Domestic Animals 2018, 53, 818-821.

17. Filliers M., Rijsselaere T., Bossaert P., Zambelli D., Anastasi P., Hoogewijs M., Van Soom A.: In vitro evaluation of fresh sperm quality in tomcats: a comparison of two collection techniques. Theriogenology 2010, 74, 31-39.

18. Fuku E., Xia L., Downey B. R.: Ultrastructural changes in bovine oocytes cryopreserved by vitrification. Cryobiology 1995, 32, 139-156. 
19. Gajda B., Rajska I.: Aktualny stan i możliwości kriokonserwacji zarodków i oocytów zwierząt gospodarskich. Roczniki Naukowe Polskiego Towarzystwa Zootechnicznego 2014, 10, 89-111.

20. Hasler J. F., McCauley A. D., Schermerhorn E. C., Foote R. H.: Superovulatory responses of Holstein cows. Theriogenology 1983, 19, 83-99.

21. Hasler J. F.: Forty years of embryo transfer in cattle: A review focusing on the journal Theriogenology, the growth of the industry in North America, and personal reminisces. Theriogenology 2014, 81, 152-169.

22. Hasler J. F.: The current status and future of commercial embryo transfer in cattle. Animal Reproduction Science 2003, 79, 245-264.

23. Hayakawa H., Hirai T., Takimoto A., Ideta A., Aoyagi $Y$ : Superovulation and embryo transfer in Holstein cattle using sexed sperm. Theriogenology 2009, 71, 68-73.

24. Hermes R., Göritz F., Streich W. J., Hildebrandt T. B.: Assisted reproduction in female rhinoceros and elephants - Current status and future perspective. Reproduction in Domestic Animals 2007, 42, 33-44

25. Hussain S. A., Lessard C., Anzar M.: A strategy for improvement of post thaw quality of bison sperm. Theriogenology 2013, 79, 108-115.

26. Jakiel M.: Przebieg porodów i okołoporodowa śmiertelność cieląt - przyczyny i konsekwencje. Wiadomości Zootechniczne 2018, 3, 36-43.

27. Jones Jr. H. W., Acosta A. A., Garcia J.: A technique for the aspiration of oocytes from human ovarian follicles. Fertility and Sterility 1982, 37, 26-29.

28. Kochan J., Niżański W., Moreira N., Cubas Z. S., Nowak A., Prochowska S., Partyka A., Młodawska W., Skotnicki J.: ARTs in wild felid conservation programmes in Poland and in the world. Journal of Veterinary Research 2019, 63 , 457-464.

29. Kopera I., Szczepanowicz M., Giżejewski Z., Sadowska J., Bilińska B. Immunoexpression of aromatase in immature and adult males of the European bison (Bison bonasus, Linnaeus 1758). Reproduction in Domestic Animals 2010, 45, 269-274.

30. Kozdrowski R., Niżański W., Dubiel A., Olech W.: Possibilities of using the European bison (Bison bonasus) epididymal spermatozoa collected post-mortem for cryopreservation and artificial insemination: a pilot study. Reproductive Biology and Endocrinology 2011, 9, 31 .

31. Kruip Th. A. M., den Daas J. H. G.: In vitro produced and cloned embryos: Effects on pregnancy, parturition and offspring. Theriogenology 1997, 47, 43-52.

32. Kunowska-Slosarz M., Baumgart U., Boruta A.: Metody pozyskiwania, oceny i selekcji oocytów psa domowego. Med. Weter. 2014, 70, 330-335.

33. Lermen D., Blömeke B., Browne R., Clarke A., Dyce P. W., Fixemer T., Fuhr G. R., Holt W. V., Jewgenow K., Lloyd R. E., Lötters S., Paulus M., Reid G. M., Rapoport D. H., Rawson D., Ringleb J., Ryder O. A., Spörl G., Schmitt T., Veith M., Müller P.: Cryobanking of viable biomaterials: implementation of new strategies for conservation purposes. Molecular Ecology 2009, 18, 1030-1033.

34. Lessard C., Danielson J., Rajapaksha K., Adams G. P., Mc Corkell R.: Banking North American buffalo semen. Theriogenology 2009, 71, 1112-1119.

35. Luvoni G. C.: Gamete cryopreservation in the domestic cat. Theriogenology 2006, 66, 101-111

36. Mansour R. T., Aboulghar M. A., Serour G. I.: Study of the optimum time for human chorionic gonadotropin - Ovum pickup interval in in vitro fertilization. Journal of Assisted Reproduction and Genetics 1994, 11, 478-481.

37. Marchi da Silva B. L., Adona P. R., Guemra S., Monzani P. S. dos Santos Miranda M.: Ovum pick up: cows treated with single doses of follicle stimulating hormone. Journal of Agricultural Science 2019, 11, 231-239.

38. Martinez-Pastor F., Garcia-Macias V., Alvarez M., Chamorro C., Herraez P, de Paz P., Anel L.: Comparison of two methods for obtaining spermatozoa from the cauda epididymis of Iberian red deer. Theriogenology 2006, 65, 471-485.

39. Martins C. F. Driessen K. Melo Costa P. Carvalho-Neto J O de Sousa R. V. Rumpf R., Dode M. N.: Recovery, cryopreservation and fertilization potential of bovine spermatozoa obtained from epididymides stored at $5{ }^{\circ} \mathrm{C}$ by different periods of time. Animal Reproduction Science 2009, 116, 50-57.

40. Max A.: Biotechnologia rozrodu w ratowaniu zagrożonych gatunków zwierząt. Życie Wet. 2017, 92, 105-108.

41. Morrow C. J., Penfold L. M., Wolfe B. A.: Artificial insemination in deer and non-domestic bovids. Theriogenology 2009, 71, 149-165.

42. Muñoz-Fuentes V., Linde Forsberg C., Vilà C., Morrell J. M.: Single-layer centrifugation separates spermatozoa from diploid cells in epididymal samples from gray wolves, Canis lupus. Theriogenology 2014, 82, 773-776.

43. Nichi M., Rijsselaere T., Losano J., Angrimani D., Kawai G., Goovaerts I., Van Soom A., Barnabe V. H., De Clercq J., Bols P.: Evaluation of epididymis storage temperature and cryopreservation conditions for improved mitochondrial membrane potential, membrane integrity, sperm motility and in vitro fertilization in bovine epididymal sperm. Reproduction in Domestic Animals 2017, 52, 257-263

44. Niżański W., Mikołajewska N., Partyka A., Ochota M.: Biotechniki w rozrodzie kotowatych - stan wiedzy, perspektywy i wyzwania. Med. Weter. 2012, 68, 529-533

45. Olech W: Analysis of inbreeding in European bison. Acta Theriologica 1987, 32, 373-387.

46. Olech $W$.: The changes of founders' number and their contribution to the European bison population during 80 years of species' restitution. European Bison Conservation Newsleter 2009, 2, 54-60.

47. Peippo J., Vartia K., Kananen-Anttila K., Räty M., Korhonen K., Hurme T., Myllymäki H., Sairanen A., Mäki-Tanila A.: Embryo production from superovu- lated Holstein-Friesian dairy heifers and cows after insemination with frozenthawed sex-sorted X spermatozoa or unsorted semen. Animal Reproduction Science 2009, 111, 80-92.

48. Pérez-Garnelo S. S., Garde J., Pintado B., Borque C., Talavera C., Delclaux M., López M., De La Fuente Martínez J.: Characteristics and in vitro fertilizing ability of giant panda (Ailuropoda melanoleuca) frozen-thawed epididymal spermatozoa obtained 4 hours post mortem: A case report. Zoobiology 2004, 23, 279-285.

49. Pérez-Garnelo S. S., Oter M., Borque C., Talavera C., Delclaux M., MartínezNevado E., Palasz A. T., De la Fuente J.: Post-thaw viability of European bison (Bison bonasus) semen frozen with extenders containing egg yolk or lipids of plant origin and examined with a heterologous in vitro fertilization assay. Journal of Zoo and Wildlife Medicine 2006, 37, 116-125.

50. Pope C. E., Gómez M. C., Cole A., Dumas C., Dresser B. L.: 229 Oocyte recovery, in vitro fertilization and embryo transfer in the serval (Leptailurus serval). Reproduction, Fertility and Development 2005, 18, 223-223.

51. Prieto Pablos M. T., Sánchez-Calabuig M. J., Hildebrandt T. B., SantiagoMoreno J.: Sperm cryopreservation in wild animals. European Journal of Wildlife Research 2014, 60, 851-864.

52. Pucek Z., Belousova I. P., Krasińska M., Krasiński Z. A., Olech W.: European bison. Status Survey and Conservation Action Plan. Gland, Switzerland and Cambridge, UK IUCN/SSB Bison Specialist Group IUCN 2004, 1-54.

53. Purdy P. H., Graham J. K.: Effect of cholesterol-loaded cyclodextrin on the cryosurvival of bull sperm. Cryobiology 2004, 48, 36-45.

54. Pusey A., Wolf M.: Inbreeding avoidance in animals. Trends in Ecology \& Evolution 1996, 11, 201-206.

55. Rails K., Ballon J.: Effects of inbreeding on infant mortality in captive primates International Journal of Prímatology 1982, 3, 491-505.

56. Santl B., Wenigerkind H., Schernthaner W., Mödl J., Stojkovic M., Prelle K., Holtz W., Brem G., Wolf E.: Comparison of ultrasound-guided vs laparoscopic transvaginal ovum pick-up (OPU) in simmental heifers. Theriogenology 1998 , 50, 89-100.

57. Saragusty J., Arav A.: Current progress in oocyte and embryo cryopreservation by slow freezing and vitrification. Reproduction 2011, 141, 1-19.

58. Serret C. G., Alvarenga M. V. F., Cória A. L. P., Dias C. P., Corcini C. D., Corrêa M. N., Deschamps J. C., Bianchi I., Lucia Jr. T.: Intrauterine artificial insemination of swine with different sperm concentrations, parities, and methods for prediction of ovulation. Animal Reproduction 2005, 2, 250-256.

59. Shaken M., Mamoei M., Roshanfekr H., Mirzadeh Kh.: Effect of epididymis handling conditions on the quality of ram spermatozoa recovered post-mortem. Asian Journal of Animal and Veterinary Advances 2008, 3, 400-408

60. Singina G. N., Bagirov V. A., Danch S. S., Taradainik T. E., Dotsev A. V., Zinovieva $N$. A.: In vitro production of interspecies hybrid embryos of cattle (Bos taurus) and wisent (Bison bonasus). Agricultural Biology 2016, 51, 824-829.

61. Slanina T., Miškeje M., Tirpák F., Błaszczyk M., Formicki G., Massányi P.: Caffeine strongly improves motility parameters of turkey spermatozoa with no effect on cell viability. Acta Veterinaria Hungarica 2018, 66, 137-150.

62. Slatis M. A.: An analysis of inbreeding in the European bison. Genetics 1960 , 45, 275-287.

63. Thibier M., Wagner H. G.: World statistics for artificial insemination in cattle. Livestock Production Science 2002, 74, 203-212.

64. Thomassen R., Farstad W.: Artificial insemination in canids: A useful tool in breeding and conservation. Theriogenology 2008, 71, 190-199.

65. Thomassen R., Sanson G., Krogences A., Fougner J. A., Andersen Berg K., Farstad $W$.: Artificial insemination with frozen semen in dogs: A retrospective study of 10 years using a non-surgical approach. Theriogenology 2006, 66, $1645-1650$

66. Toosi B. M., Tribulo A., Lessard C., Mastromonaco G. F., McCorkell R. B., Adams G. P.: Superovulation and embryo transfer in wood bison (Bison bison athabascae). Theriogenology 2013, 80, 542-551.

67. Wieczorek J., Kosenjuk J., Cegła M., Kątska L.: Efektywność aspiracji oraz jakość oocytów kozich uzyskiwanych laparoskopową metodą OPU. Med. Weter 2009, 65, 272-276.

68. Wieczorek J., Kosenyuk Y., Cegła M., Ryńska B.: A new concept in laparoscopic ovum pick-up (OPU) in sheep - efficiency of method and morphology of recovered oocytes. Annals of Animal Science 2010, 10, 39-48.

69. Wieczorek J., Kosenyuk J., Skrzyszowska M., Cegła M.: L-OPU in goat and sheep - different variants of the oocyte recovery method. Animals 2020, 10, 658.

70. Wittayarat M., Kimura T., Kodama R., Namula Z., Chatdarong K., Techakumphu M., Sato Y., Taniguchi M., Otoi T.: Long-term preservation of chilled canine semen using vitamin $\mathrm{C}$ in combination with green tea polyphenol. Cryo Letters 2012, 33, 318-326.

71. Yang S. X., Adams G. P., Palomino J. M., Huanca W. F., Lessard C., Rajapaksha K., Anzar M.: Cryopreservation of bison semen without exogenous protein in extender and its fertility potential in vitro and in vivo following fixedtime artificial insemination. Theriogenology 2020, 152, 156-164.

Corresponding author: Maria Eberhardt, DVM, Department of Reproduction and Clinic of Farm Animals, Veterinary Faculty, University of Environmental Science, pl. Grunwaldzki 49, 50-357 Wroclaw; e-mail: maria.eberhardt@upwr.edu.pl 